\title{
Abundance and biomass estimation of this summer individuals of alien fish species in Zaporizke reservoir
}

\author{
O.N. Marenkov \\ Oles Gonchar Dnepropetrovsk National University, Dnepropetrovsk, Ukraine \\ E-mail: gydrobionts@gmail.com \\ Submitted: 03.12.2017. Accepted: 10.01.2018
}

Substantial changes in the hydroecosystem of the Zaporizke reservoir have led to a significant transformation of aquatic biocoenoses. As a result, number of some aboriginal fish species have decreased. The regulation of the Dnipro river has contributed to the spread of new species of fish. Over the past 30 years, the ichthyofauna of the reservoir has gained about 20 species of fish that acclimatized and expanded their range. The article presents the results of ichthyological research of 20102016. The article determines main causes of the spread of new species of fish, and gives the results of complex monitoring studies on the number and biomass of young alien fish species of the Zaporizke reservoir. It was found that the most numerous first summer individuals of alien fish species are big-scale sand smelt Atherina pontica(Eichwald, 1831), Prussian carp Carassius gibelio (Bloch, 1782), topmouth gudgeon Pseudorasbora parva(Temminck et Schlegel, 1846), black-striped pipefish (Syngnathus abaster Risso, 1826) and pumpkinseed Lepomis gibbosus (Linnaeus, 1758).

Key words: alien species; first summer fish; Zaporizke reservoir; ichthyofauna

\section{Introduction}

Under the intensive anthropogenic impact, freshwater ecosystems are most vulnerable ones on the planet (Volke et al., 2015). During the transformation of aquatic ecosystems, the dynamic characteristics of both entire group and its individual elements, were changing (Johnson et al., 2014; Volke et al., 2015). Due to insufficient ecological plasticity, number of some aboriginal fish species have critically reduced. It is considered that one of the reasons for reducing habitats and number of aboriginal species is the spread of alien hydrobionts, which dominate by the level of physiological polyvalence (Douglas et al, 2015). Some species of fish are in the ponds of the Dnipro River for short time, but they are rapidly increasing their numbers and creating competition for native species. For example, the pumpkinseed Lepomis gibbosus (Linnaeus, 1758) got to the Zaporizhske reservoir 15 years ago (Holoborodko et al., 2016), but it is already found in Samara Bay. In the summer, its capture reaches $200 \mathrm{~kg}$ daily. Such changes in hydrobiocoenoses of water bodies damage the fish industry. Since the Ukrainian reservoirs are the "gate" for biological invasions of Europe's reservoirs, determining the number and biomass of alien species of fish will provide the development of short-term and long-term forecasts for assessing their impact on aboriginal ichthyotcoenoses and determination of their impact on the biological productivity of water bodies (Lotz \& Allen, 2013)

The results of current researches devoted to the studies of biology, ecology, and spreading of invasive species in multiplepurpose water bodies (Douglas et al, 2015), as well as the socio-economic consequences of biological invasions (Lotz \& Allen, 2013).

Active people 's economic activity, regulation of the flow of the Dnieper River and its tributaries caused significant changes in the existence conditions and biological diversity of the ichthyofauna of the ponds of the steppe Prydniprovya (Holoborodko et al., 2016). Only in the last 30 years the ichthyofauna of the Dnieper has enriched by almost 20 species of fish, which have acclimated, expanded their area and now they have their functions in the ecosystem.

The anthropogenic factors influencing the species composition of ichthyocenosis include technical and fishery factors (Bulakhov et al., 2008, Douglas et al., 2015). Technical impact on reservoirs is associated with the creation of artificial reservoirs such as various reservoirs, heat sinks, irrigation canals, etc. Fishery measures include the introduction of new species of fish into reservoirs, which has both advantages and disadvantages (Semenchenko et al., 2015). The study of the current state of ichthyocenosis for solving important economic issues regarding the conservation, enrichment and rational use of aquatic biological resources is the basis for studying the biodiversity of fish under conditions of continuous invasive process. 


\section{Materials and methods}

Research fishing was carried out on the basis of permits issued by the State Agency of Fisheries of Ukraine (№ DKRG 044, № DKRG 045 in 2010, № DKRG 035, DKRG 036 in 2011), Department of Protection, Use and Reproduction of Water Bioresources and regulation of fishing in the Dnipropetrovsk region (№ 0001, № 0002 in 2012, № 0001 , № 0002 in 2013, № 000037 , № 000038 in 2014, № 000030, № 000031 in 2015-2016) within the limits of allocated quotas and approved work programs of scientific research works. The first summer fish $(0+)$ were caught from the third decade of July till the first decade of August in the shallow waters of the Zaporizhske reservoir at standard control points. The catches were carried out with a 10-meter minnow seine with height of $1 \mathrm{~m}$, made of bolting cloth № 7 and tuck seine of nylon with a $4 \mathrm{~mm}$ mesh size. The relative number of first summer fish was accepted as the number of young fish per 100 square meters of the catching area. Species of fish were determined by A. F. Koblitskaya (Koblitskaia, 1981). Species names of fish are provided according to the current version of fishbase.org (Froese \& Pauly, 2017).

\section{Results and Discussion}

Currently, about one third of the fish species of the Zaporizhske reservoir are adventive, they have not fully implemented the adaptation potential, and the effect of their introduction is still difficult to predict. Similar changes in the structure of the reservoir's ichthyofauna can damage both the ecosystem of the reservoir and the fish industry, since invasive fish are often food rivals of young industrial or rare species of fish.

At all stages of the existence of the Zaporizhske reservoir, the ichthyofauna of the reservoir has significantly transformed (Fedonenko et al., 2008). According to various estimates, in the structure of the modern ichthyofauna of reservoir there are 52 species of fish, which are representatives of 14 families. Compared to the river period of the Dnipro River, its number of fish remained at the same level, but the species composition of the ichthyofauna changed radically due to the distribution of new species of fish (Table 1).

Table 1. Distribution of new species of fish in the basin of Zaporizhske reservoir

\begin{tabular}{|c|c|c|c|}
\hline № & Species of fish & Years & References \\
\hline 1. & $\begin{array}{l}\text { Black-stripped pipefish } \\
\text { Syngnathus abaster Risso, } 1826\end{array}$ & 1931 & $\begin{array}{l}\text { (Fedonenko et al., } \\
\text { 2008) }\end{array}$ \\
\hline 2. & Black and Caspian Sea sprat Clupeonella cultriventris (Nordmann, 1840) & 1958 & (Novitsky, 2010) \\
\hline 3. & Three-spined stickleback Gasterosteus aculeatus Linnaeus, 1758 & 1959 & $\begin{array}{l}\text { (Fedonenko et al., } \\
\text { 2008) }\end{array}$ \\
\hline 4. & Black sea shad Alosa pontica (Eichwald, 1838) & $\begin{array}{c}1961 \\
\text { (repeatedly) }\end{array}$ & $\begin{array}{l}\text { (Novitsky \& } \\
\text { Semenova, 2010) }\end{array}$ \\
\hline 5. & Grass carp Ctenopharyngodon idella (Valenciennes, 1844) & $1960-1970$ & $\begin{array}{l}\text { (Fedonenko et al., } \\
\text { 2008) }\end{array}$ \\
\hline 6. & Prussian carp Carassius gibelio (Bloch, 1782) & 1970 & $\begin{array}{l}\text { (Fedonenko et al., } \\
\text { 2008) }\end{array}$ \\
\hline 7. & Bighead carp Aristichthys nobilis (Richardson, 1845) & 1970 & $\begin{array}{l}\text { (Fedonenko et al., } \\
\text { 2008) }\end{array}$ \\
\hline 8. & Silver carp Hypophthalmichthys molitrix (Valenciennes, 1844) & 1970 & $\begin{array}{l}\text { (Fedonenko et al., } \\
\text { 2008) }\end{array}$ \\
\hline 9. & Big-scale sand smelt Atherina pontica (Eichwald, 1831) & 1990 & (Ermilov et al., 1991) \\
\hline 10. & Stone moroco Pseudorasbora parva (Temminck et Schlegel, 1846) & 1992 & $\begin{array}{l}\text { (Kochet \& Khristov, } \\
\text { 1998) }\end{array}$ \\
\hline 11. & Knout goby Mesogobius batrachocephalus (Pallas, 1814) & 1995 & $\begin{array}{l}\text { (Khristov \& Novitsky, } \\
\text { 1997) }\end{array}$ \\
\hline 12. & Channel catfish Ictalurus punctatus (Rafinesque, 1818) & 1996 & (Novitsky, 2002) \\
\hline 13. & Pumpkinseed Lepomis gibbosus (Linnaeus, 1758) & $\begin{array}{c}1992-1993 \\
2002\end{array}$ & $\begin{array}{l}\text { (Fedonenko \& } \\
\text { Marenkov, 2013) }\end{array}$ \\
\hline 14. & Brauner's tadpole-goby Benthophiloides brauneri Beling et Iljin, 1927 & 2006 & $\begin{array}{l}\text { (Novitsky et al., } \\
\text { 2008) }\end{array}$ \\
\hline 15. & Azov percarina Percarina demidoffii (Nordmann, 1840) & 2012 & Our data \\
\hline
\end{tabular}

In recent years, there was an intensive process of reforming the species composition of the Zaporizhske reservoir fauna. The complex of anthropogenic and ecological factors, which caused radical changes in ichthyocenosis, has significantly influenced the structure of the ichthyofauna. An increase in the number of species is caused by several factors. First of all, after the disappearance of the Dnieper rapids and with the increase of mineralization, the process of self-resettlement (Fedonenko et al., 2008) began, resulting the appearance of the following species of fish from the southern regions: the Black sea shad $A$. pontica (Eichwald, 1838), (Bulakhov et al., 2008; Novitsky \& Semenova, 2010), the Three-spined stickleback G. aculeatus 
(Linnaeus, 1758), the Black-stripped pipefish S. abaster Risso, 1826 (Fedonenko et al., 2016), the big-scale sand smelt $A$. pontica (Eichwald, 1831), the Black and Caspian Sea sprat C. cultriventris (Normann, 1840), Brauner's tadpole-goby B. brauneri (Beling et Iljin, 1927), Azov percarina P. demidoffii (Nordmann, 1840).

Second reason is the process of fish introduction for the fishery exploitation of the reservoir: silver carp $H$. molitrix (Valenciennes, 1844) and bighead carp A. nobilis (Richardson, 1845), grass carp C. idella (Valenciennes, 1844), Prussian carp C. Gibelio (Bloch, 1782), channel catfish I. punctatus (Rafinesque, 1818). Together with the bait of the herbivorous fish of the Far Eastern complex, a Stone moroko P. parva (Temminck et Schlegel, 1846), has entered the reservoir, which unlike the silver carp and grass carp, was acclimated and extended its area throughout the water area of the Zaporizhske reservoir and its subterranean river systems (Bulakhov et al., 2008; Fedonenko et al., 2008).

The appearance of new species was also associated with the deliberate release of exotic fish. Thus, in the reservoirs of the Dnipropetrovsk region, pumpkinseed L. gibbosus (Linnaeus, 1758) has appeared and it was well acclimatized and broadly extended its habitat (Fedonenko et al., 2015). Since this alien species is a predator, it can potentially damage valuable industrial fish species, since it feeds on invertebrates, and sometimes eggs and young fish. Each year, within the industrial agglomerations, there are marked catches of single aquarium exotics (Kochet et al., 2002), for example, guppy, representatives of the family Poeciliidae, ancistrus, representatives of the family Loricariidae, plectotomyces of the family Loricariidae, astronotus, Cichlidae, and even piranhas, Characidae, which have entered the reservoir as a result of the intentional issue by careless aquarists.

Annual monitoring of coastal areas of the reservoir allows determination of the species composition of the ichthyofauna and estimation of the number and biomass of fish.

Among the studied first summer fish of alien species, the greatest number and biomass had Prussian carp C. gibelio (Bloch, 1782); in the long-term aspect during 2010-2016, its number ranged from 6.60 ind./100 $\mathrm{m}^{2}$ (2013 indicator) to 16.45 ind./100 $\mathrm{m}^{2}$ (2016 indicator). The average annual number and biomass of Prussian carp `s first summer fish reached 11.51 ind./100 $\mathrm{m}^{2}$ and $43.39 \mathrm{~g} / 100 \mathrm{~m}^{2}$, respectively. Although in some parts of the reservoir (Samara Bay, the creek of the Mokra Sura River), its number reached 140.2-228.45 ind./100 $\mathrm{m}^{2}$. The large number of Prussian carp 's yearlings support the industrial stock of this species, which in 2011 took the first place in the industrial catches of the Zaporizhske reservoir and was 170-200 tons/year, which is almost 6 times higher than in 2004. A similar increase in the number and biomass of Prussian carp indicates the ecological plasticity of the species and its adaptive potential to the conditions of the reservoir.

Table 2. Analysis of the number and biomass of first summer fish (0+) of alien species in the Zaporizhske reservoir, calculation per the $100 \mathrm{~m}^{2}$ of shallow water areas.

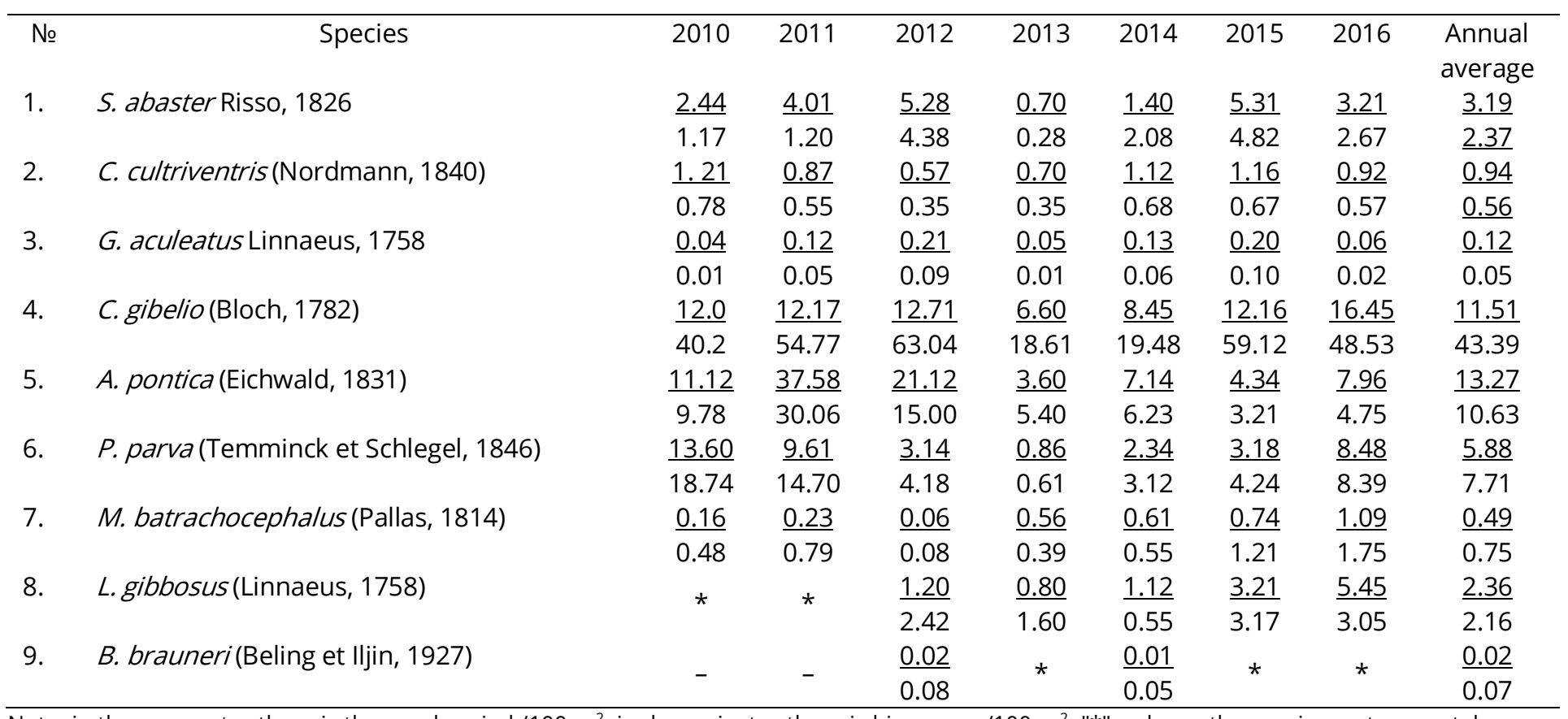

Note: in the numerator there is the number, ind./100 $\mathrm{m}^{2}$; in denominator there is biomass, $\mathrm{g} / 100 \mathrm{~m}^{2}$; " " - shows the species met separately;

"-" - shows that the species did not appear in catches.

Minor figures of the number characterized the Knout goby M. batrachocephalus (Pallass, 1814) and Brauner's tadpole-goby $B$. brauneri (Beling et Iljin, 1927) and were 0.49 and 0.02 per $100 \mathrm{~m}^{2}$, respectively, but the catch of gobies by the tuck seine was hampered by the fact that the gobies are hiding in burrows or under stones, where allowed gear is not always effectively used. Of course, it would be desirable to use dredges or electro-devices for the perfect catches of the gobies, as used by the ichthyologists of Europe and America.

The Black and Caspian Sea sprat is a planktophagus, which acts as a food competitor to fish fries and herbivorous species (grass carp). In the period of research, the number of sprat `s first summer fish varied from 0.57 ind./100 $\mathrm{m}^{2}$ (2013) to 1.21 ind./100 $\mathrm{m}^{2}$ (2010). The annual multi-year indicator of the number and biomass of this species reaches 0.94 ind./100 $\mathrm{m}^{2}$ and $0.56 \mathrm{~g} / 100$ $\mathrm{m}^{2}$ respectively. There are reservations that such indicators are quite understated, because the sprat is not always concentrated in littoral, but it is usually found in the pelagial of reservoir. About the potentially high number of sprat says its industrial 
development by fishermen in separate seasons of the year, so during the last 5 years, according to official industrial statistics, its catches in the Zaporizhske reservoir have reached 123.9-199.55 tons/year.

Studies of 2010-2016 have shown that the largest number first summer pipefish in Zaporizhske reservoir was recorded in 2015 and amounted to 5.31 ind./100 $\mathrm{m}^{2}$ of shallow areas of the pond. Biomass, created by pipefish ranged from $0.28 \mathrm{~g} / 100 \mathrm{~m}^{2}$ (indicator of 2013) to $4.82 \mathrm{~g} / 100 \mathrm{~m}^{2}$ (indicator of 2015). The average index of number and biomass of first summer pipefish in Zaporizhske reservoir reached 3.32 ind./100 $\mathrm{m}^{2}$ and $2.57 \mathrm{~g} / 100 \mathrm{~m}^{2}$ respectively. It should be noted that the number of this species in some parts of the reservoir (in the Samara Bay, near the village of Stari Kodaki, near Voloske village) is very high and can reach 38.0-52.1 ind./100 $\mathrm{m}^{2}$. Due to its large number in the littoral zone of ponds pipefish may be significant trophic competitor for other fish species.

Today is quite difficult to predict the number of pumpkinseed in Zaporizhske reservoir, but due to the fact that this species is well adapted to the environmental conditions of the region and quickly acclimates in reservoirs of Dnipropetrovsk region, its population increases. If in scientific catches in the waters of Zaporizhske reservoir in 2011 there were recorded isolated cases of catching pumpkinseed, from 2013-2014 years there were found local habitat of pumpkinseed in the reservoir and its tributaries, and the number of first summer fish of this species reached 0.03 ind./100 $\mathrm{m}^{2}$ in Samara Bay and 0.8-5.45 ind./100 $\mathrm{m}^{2}$ in the reservoir.

During scientific control catches in May 2012 in the Samara Bay near the village Odynkivka, the pumpkinseed was encountered in such fishing gear as gill nets with a mesh size of 30-32 mm. And already in 2016 during the works at the control and monitoring station in the waters of the Samara Bay in the village. Novoselivka from 10.06.2016 to 30.06.2016 during the analysis of industrial catches from stack nets with a step a=30 mm there was catched from 20 to $200 \mathrm{~kg}$ of pumpkinseed daily (Fig. 1).

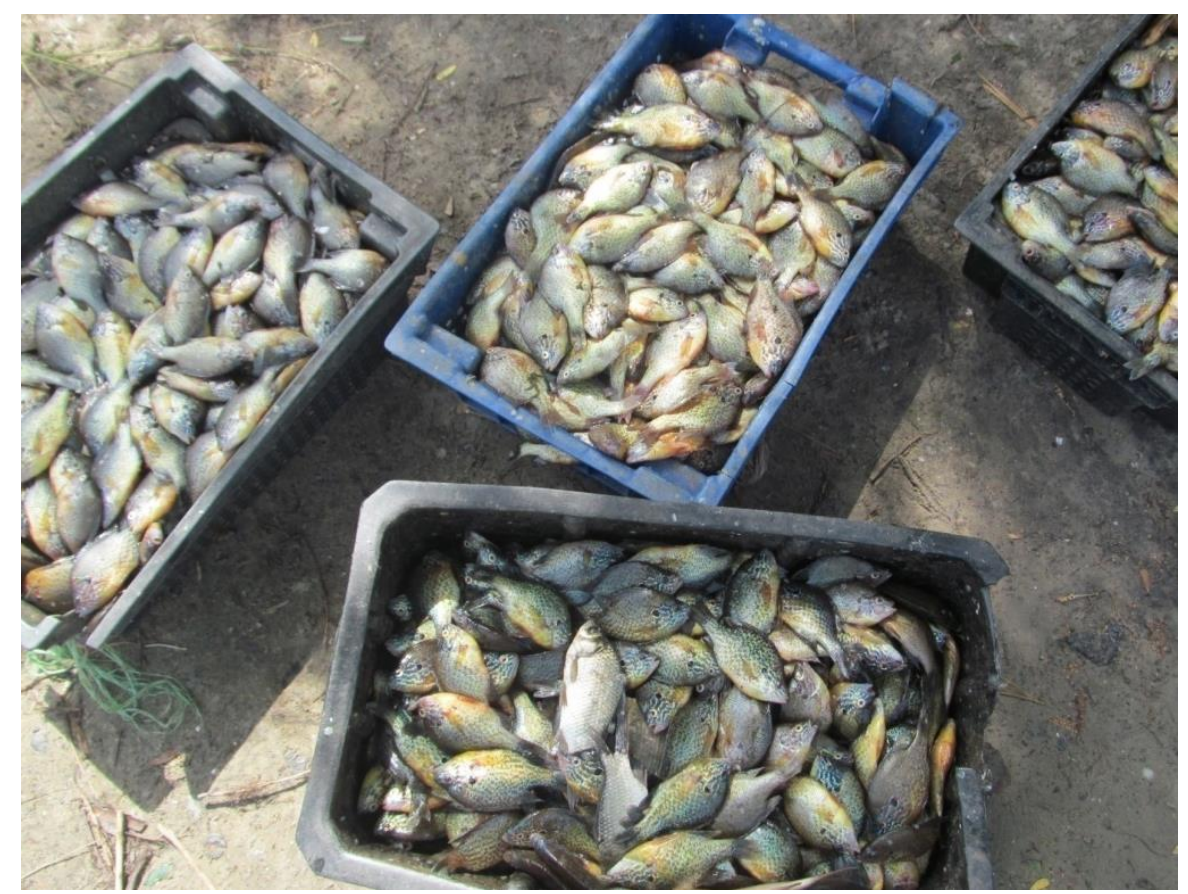

Figure 1. Pumpkinseed catches in 2016.

This species does not have an industrial significance, but the question arises about its posting at fish receptions and consideration as a partial species in the fishery in the Zaporizhske water reservoir. It is recommended to allow swordfish catches without limitation and forecasting. We advised on the inclusion of the pumpkinseed in the regulatory documents regarding the procedure for industrial fishing in the Zaporizhske reservoir in 2017, in particular the project "Limits and forecasts of admissible special use of water bioresources of national importance in Dnipro reservoirs in 2017".

Stone moroco P. parva (Temminck et Schlegel, 1846) is characterized by a great ability to spread and develop in new reservoirs. In the Dnipropetrovsk region it is found almost everywhere. It occurs in some flooded quarries (village Stary Kodaki), spreads throughout the water area of the Zaporizhzhya (Dnipro) reservoir. The number of its first summer fish per $100 \mathrm{~m}^{2}$ of littoral of the reservoir fluctuates each year and an average of 7 years of research is 5.88 with a biomass of $7.71 \mathrm{~g} / 100 \mathrm{~m}^{2} . \mathrm{In}$ some years, at some sites, the number of its first summer fish reached 48.13 per 100 square meters $(2015$, near Voyskove village) and 87.53 per 100 square meters (2016, near Stary Kodaki). This species does not have industrial value and acts as a food competitor. The number of big-scale sand smelt's first summer fish $A$. pontica (Eichwald, 1831) ranged from 3.60 ind./100 m² (2013) to $37.58 \mathrm{ind} . / 100 \mathrm{~m}^{2}$; the average long-term rate of number and biomass of this species was $13.27 \mathrm{ind} . / 100 \mathrm{~m}^{2} \mathrm{and} 10.63 \mathrm{~g} / 100 \mathrm{~m}^{2}$ respectively.

First summer individuals of such species as the Azov percarina P. demidoffii (Nordmann, 1840), channel catfish /. punctatus (Rafinesque, 1818), Black sea shud $A$. pontica (Eichwald, 1838) were cathed by tuck seine extremely rare, because the species have a limited number and local habitats. In catches there were not found first summer silver carp $H$. molitrix (Valenciennes, 1844), bighead carp A. nobilis (Richardson, 1845) and grass carp C. idella (Valenciennes, 1844), since these species of fish do not 
reproduct in the reservoir, and their number is supported by the annual artificial livelihoods of the reservoir for the purpose of fishing development.

Thus, the genesis of Zaporizhske reservoir fish fauna is still ongoing and it is connected with the subsequent emergence of new species and increase of their numbers and biomass.

\section{Conclusions}

In recent years, there is an intensive reforming the species composition in fauna of the Zaporizhske reservoir. Currently, about one third of the fish species of the Zaporizhske reservoirs are adventitious, they have not fully realized the potential of adaptation, and the effect of their introduction is still difficult to predict.

The main reasons for the spread of new fish species in the basin of the Zaporizhske reservoir include the disappearance of the Dnieper rapids and the increase in the mineralization of water. These events launched a process of self-resettlement, resulting appearance of some marine species of fishes in reservoir from the southern regions. As a result of the fishery exploitation of the reservoir, such species as the silver carp, grass carp, bighead, Prussian carp, Stone moroco and channel catfish are caught in it. As a result of the deliberate release of exotic fish, a pumpkinseed got to the reservoir, and widespreads its area.

\section{References}

Bulakhov, V.L., Novitskiy, R.O., Pakhomov, O.Y., \& Hristov, O.A. (2008). Biological diversity of Ukraine. Dnipropetrovsk region. Cyclostomes (Cyclostomata). Fish (Pisces). Dnipropetrovsk University Press, Dnipropetrovsk (in Ukrainian).

Douglas, M.R., Slynko, Y. V., Dgebuadze, Y. Y., Olenin, S., Aleksandrov, B., Boltachev, A., Slynko, E.E., Khristenko, D., Minchin, D., Pavlov, D.F., Reshetnikov, A.N., Vekhov, D.A., Ware, C.J., \& Douglas, D.E. (2015). Invasion ecology: an international perspective centered in the Holarctic. Fisheries, 40(9), 464-470. doi: 10.1080/03632415.2015.1075344

Ermilov, S.N., Zagubizhenko, N.I., Tarasenko, S.N., \& Khristov, O.A. (1991). Ecological assessment of the state of fish stocks in the Zaporizhzhya reservoir and ways to improve them. Problems of rational use and protection of water resources in the Dnipro Basin, 29-30. (in Russian).

Fedonenko, E.V., \& Marenkov, O.N. (2013). Spreading, spatial distribution, and morphometric Characteristic of the Pumpkinseed Sunfish Lepomis gibbosus (Centrarchidae, Perciformes) in the Zaporozhye reservoir. Russian Journal of Biological Invasions, 4(3), 194199. doi: $10.1134 / S 207511171303003 X$

Fedonenko, O., Marenkov, O., Stromenko, A., \& Kolesnik, N. (2016). Reproductive biology and quantity evaluation of the Black-striped pipefish Syngnathus abaster (Eichwald, 1831) in the Zaporozhian reservoir. International Letters of Natural Sciences, (52): 54-59. doi: 10.18052/www.scipress.com/ILNS.52.54

Fedonenko, O.V., Yesipova, N.B., \& Sharamok, T.S. (2008). Ecological state of biocenoses of Zaporizhzhya reservoir in modern conditions. Dnipropetrovsk (in Ukrainian).

Froese R., Pauly, D. (2017). FishBase. World Wide Web electronic publication. Available from: http://www.fishbase.org, Accessed on 20.12.2017.

Holoborodko, K.K., Marenkov, O.M., Gorban, V.A., \& Voronkova, Y.S. (2016). The problem of assessing the viability of invasive species in the conditions of the steppe zone of Ukraine. Visnyk of Dnipropetrovsk University Biology, Ecology, 24(2), 466-472. doi: $10.15421 / 011663$

Johnson, W.C., Volke, M.A., Scott, M.L., \& Dixon, M.D. (2015). The dammed Missouri: prospects for recovering Lewis and Clark's River. Ecohydrology, 8(5), 765-771. doi: 10.1002/eco.1534

Khristov O.A., \& Novitsky R.A. (1997). A qualitative change in the ichthyofauna of the Dnieper reservoir: the crisis of predatory fish species and measures to prevent it. France and Ukraine, scien-pract. Experience in the context of the dialogue of national cultures: mat. IV International Conf. - Dnipropetrovsk, Vol.2, part 2., 58. (in Ukrainian).

Koblitskaia, A.F. (1981). Determinant of freshwater fish juvenile. Moscow, Nauka Publ. (in Russian).

Kochet, N.V., \& Khristov, O.A. (1998). Current state of fauna of Orel River. Science and Education-98: mat. of 1 st International. Conf. Dnipropetrovsk. Ecology. Biology, 998.

Kochet, V.N., Novitsky, R.A., Khristov, O.A., \& Ushchapovsky, I.P. (2002). Exotic fishes in reservoirs of the Dnipropetrovsk region. Fisheries of Ukraine. 3-4, 16. (in Ukrainian).

Lotz, A., Allen, C.R. (2013). Social-ecological predictors of global invasions and extinctions. Ecology and Society [online serial] $18(3), 15$. doi: 10.5751/ES-05550-180315

Novitsky, R.O. (2010). New species of hydrobionts-autoinvadors in the Dnipro Reservoir. Scientific notes of the Ternopil National Pedagogical University. Series Biology, 2 (43), 373.

Novitsky, R.O., \& Semenova, O.V. (2010). Morpho-ecological characteristics of the Pontic shad Alosa pontica pontica of the Dnipro (Zaporizhzhia) Reservoir. Questions of bioindication and ecology, 14(2), 204-214.

Novitsky, R.O., Khristov, O.O., \& Bondariev, D.L. (2008). Brauner's tadpole-goby Benthophiloides brauneri Beling et Iljin, 1927 (Gobiidae, Perciformes) as a new species of ichthyofauna of the Dnipro (Zaporizhzhya) reservoir. Bulletin of Zoology. 42(6), 524. (in Ukrainian).

Semenchenko, V.P., Son, M.O., Novitsky, R.A., Kvatch, Y.V., \& Panov, V.E. (2015). Alien macroinvertebrates and fish in the Dnieper River basin. Russian Journal of Biological Invasions, 6(1), 51-64.

Volke, M.A., Scott, M.L., Johnson, W.C., \& Dixon, M.D. (2015). The ecological significance of emerging deltas in regulated rivers. BioScience, 65(6), 598-611. doi: 10.1093/biosci/biv040

\section{Citation:}

Marenkov, O.N. (2018). Abundance and biomass estimation of this summer individuals of alien fish species in Zaporizke reservoir.

Ukrainian Journal of Ecology, 8(1), 92-96.

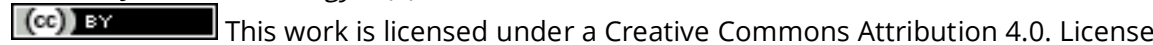

